\title{
Editorial
}

Dermatology

\section{Down Syndrome and Delayed Occurrence of Acne}

\author{
T. Simonart \\ Université Libre de Bruxelles, Brussels, Belgium
}

\begin{abstract}
Key Words
Down syndrome, puberty · Down syndrome, acne • Trisomy 21
\end{abstract}

Down syndrome (DS) is associated with an increased incidence of skin diseases which may cause further psychosocial disability in affected patients $[1,2]$. In this setting, an increased incidence of acne has been associated with DS in some previous publications [1]. Some data may support such an association. The use of anticonvulsive drugs and an altered zinc metabolism in patients with DS [3] might promote the development of acne. Overweight is also common in DS patients [4]. However, although some recent studies suggest that a high-glycemic-load diet may facilitate acne [5-8], a link between a high BMI and the development of acne is far from being proved [8].

In this issue of Dermatology, Bagatin et al. [9] found that DS patients have a low prevalence of acne, suggesting that trisomy 21 may have an unexpected protective effect against acne. Interestingly, the prevalence of acne was higher in DS patients older than 19 years than in teenagers, suggesting a delayed occurrence of acne. The authors hypothesize that, considering the possible link between stress and acne, delayed neuropsychomotor development in DS patients could lead to less psychological stress. However, despite their well-known cheerful and friendly demeanor creating a personality stereotype, approximately $20-40 \%$ of children with DS display recognized behavioral problems [10].

\section{KARGER}

Fax +4161306 1234

E-Mail karger@karger.ch

www.karger.com
(C) 2010 S. Karger AG, Basel

$1018-8665 / 10 / 2204-0321 \$ 26.00 / 0$

Accessible online at:

www.karger.com/drm
Several endocrine abnormalities are likely to contribute to a low prevalence of acne in DS patients. Androgens, such as dihydrotestosterone and testosterone, the adrenal precursor dehydroepiandrosterone sulfate, estrogens such as estradiol, and other hormones, including growth hormone and insulin-like growth factors (which are maximally secreted during adolescence), may each be important in the development of acne [11]. DS patients are known to suffer from growth hormone deficiency and inadequate insulin-like growth factor response, resulting in remarkable skeletal maturation delay and short stature [12]. DS patients also have a high incidence of abnormalities in their sexual development, and delayed puberty is reported in both sexes. Reported abnormalities in girls include hypogonadism with a delay in either menarche or adrenarche. In boys, described defects vary from ambiguous genitalia, cryptorchidism, micropenis, small testes and low sperm count to scant development of axillary hair and beard [12]. Mean levels of serum follicle-stimulating hormone and luteinizing hormone are usually markedly elevated, but mean testosterone levels are normal, which suggests a diagnosis of partial primary gonadal dysfunction [13]. Taken together, these data suggest that, despite premature aging, the onset of acne is delayed in DS patients, and support the relationship between acne and pubertal age rather than chronological age. 


\section{References}

1 Barankin B, Guenther L: Dermatological manifestations of Down's syndrome. J Cutan Med Surg 2001;5:289-293.

$>2$ Schepis C, Barone C, Siragusa M, Pettinato R, Romano C: An updated survey on skin conditions in Down syndrome. Dermatology 2002;205:234-238.

3 Marques RC, de Sousa AF, do Monte SJ, Oliveira FE, do Nascimento Nogueira N, Marreiro DN: Zinc nutritional status in adolescents with Down syndrome. Biol Trace Elem Res 2007;120:11-18.

4 Myrelid A, Frisk P, Stridsberg M, Annerén G, Gustafsson J: Normal growth hormone secretion in overweight young adults with Down syndrome. Growth Horm IGF Res 2010;20:174-178.
5 Spencer EH, Ferdowsian HR, Barnard ND: Diet and acne: a review of the evidence. Int J Dermatol 2009;48:339-347.

6 Melnik BC, Schmitz G: Role of insulin, insulin-like growth factor-1, hyperglycaemic food and milk consumption in the pathogenesis of acne vulgaris. Exp Dermatol 2009; 18 : 833-841.

7 Kurokawa I, Danby FW, Ju Q, Wang X, Xiang LF, Xia L, Chen W, Nagy I, Picardo M, Suh DH, Ganceviciene R, Schagen S, Tsatsou F, Zouboulis CC: New developments in our understanding of acne pathogenesis and treatment. Exp Dermatol 2009;18:821-832.

$\checkmark 8$ Davidovici BB, Wolf R: The role of diet in acne: facts and controversies. Clin Dermatol 2010;28:12-16.
9 Bagatin E, Souza Leao Kamamoto C, Ramos dos Santos Guadanhim L, Sanudo A, Costa Dias M, Mara Barraviera I, Consolim Colombo F: Prevalence of acne vulgaris in patients with Down syndrome. Dermatology DOI: $10.1159 / 000284680$.

10 Visootsak J, Sherman S: Neuropsychiatric and behavioral aspects of trisomy 21. Curr Psychiatry Rep 2007;9:135-140.

11 Thiboutot D, Chen W: Update and future of hormonal therapy in acne. Dermatology 2003;206:57-67.

12 Hawli Y, Nasrallah M, El-Hajj Fuleihan G: Endocrine and musculoskeletal abnormalities in patients with Down syndrome. Nat Rev Endocrinol 2009;5:327-334.

13 Hsiang YH, Berkovitz GD, Bland GL, Migeon CJ, Warren AC: Gonadal function in patients with Down syndrome. Am J Med Genet 1987;27:449-458. 